\title{
Impact of Mycorrhiza Fungi from Grassland Rhizosphere and Liquid Organic Fertilizer to the Growth and Yield of Sweet Corn on Ultisols in South Konawe, Indonesia
}

\author{
Halim $^{1}$, Makmur Jaya Arma ${ }^{1}$, Fransiscus S. Rembon ${ }^{2}$, Resman $^{3}$ \\ ${ }^{1}$ Specifications Weed Science, Department of Agrotechnology, Faculty of Agriculture, Halu Oleo University, Southeast Sulawesi, Indonesia \\ ${ }^{2}$ Specifications Soil Nutrition, Department of Agrotechnology, Faculty of Agriculture, Halu Oleo University, Southeast Sulawesi, Indonesia \\ ${ }^{3}$ Specifications Soil Science, Department of Agrotechnology, Faculty of Agriculture, Halu Oleo University, Southeast Sulawesi, Indonesia \\ Email address: \\ haliwu_lim73@yahoo.co.id (Halim),makmurarma@gmail.com (M. J. Arma), fransrembon@yahoo.com (F. S. Rembon), \\ resman_pedologi@yahoo.com (Resman)
}

\section{To cite this article:}

Halim, Makmur Jaya Arma, Fransiscus S. Rembon, Resman. Impact of Mycorrhiza Fungi from Grassland Rhizosphere and Liquid Organic Fertilizer to the Growth and Yield of Sweet Corn on Ultisols in South Konawe, Indonesia. Agriculture, Forestry and Fisheries.

Vol. 4, No. 5, 2015, pp. 209-215. doi: 10.11648/j.aff.20150405.12

\begin{abstract}
This research was conducted in the Abenggi of village, District of Landono, Regency of South Konawe, Province of Southeast Sulawesi and Laboratory of the Faculty of Forestry and Environmental Science Halu Oleo University Kendari, Indonesia took place from November, 2014 untill April, 2015. This study aims to determine the effect of mycorrhiza fungi from granssland and liquid organic fertilizer to the growth and yield of sweet corn on Ultisols Abenggi. This research is compiled using a randomized block design (RBD) with factorial pattern. The first factor are mycorrhiza fungi (M) with three levels: without mycorrhiza fungi $\left(\mathrm{M}_{0}\right)$, mycorrhiza as $20 \mathrm{~g}$ each planting hole $\left(\mathrm{M}_{1}\right)$, mycorrhiza as $40 \mathrm{~g}$ each planting hole $\left(\mathrm{M}_{2}\right)$ and second factor are liquid organic fertilizer $(\mathrm{P})$ which comprises three levels of treatment: without liquid organic fertilizer $\left(\mathrm{P}_{0}\right)$ liquid organic fertilizer as $50 \mathrm{ml} \mathrm{L}^{-1}$ water each plot $\left(\mathrm{P}_{1}\right)$, liquid organic fertilizer as $100 \mathrm{ml} \mathrm{L}^{-1}$ water each plot $\left(\mathrm{P}_{2}\right)$. The combination of these two factors obtained 9 combinations of each treatment was repeated three times in order to obtain the amount of 27 experimental units. The observed variables in this study were plant height, stem diameter, cob weight with husk, corn cob without husk, cob length, cob diameter, number and percentage of mycorrhiza infection on the roots of the sweet corn. The results showed that the interaction between mycorrhiza fungi and liquid organic fertilizer has a significant effect on the plant height age 42 days after planting and cob weight without husk with the best results obtained in the treatment of mycorrhiza as $40 \mathrm{~g}$ hole $^{-1}$ with liquid organic fertilizer as $50 \mathrm{ml} \mathrm{L}^{-1}$ water. Application the mycorrhiza fungi as $40 \mathrm{~g}$ hole ${ }^{-1}$ gives the best results on the growth and yield of sweet corn.
\end{abstract}

Keywords: Sweet Corn, Mycorrhiza Fungi, Liquid Organic Fertilizer, Ultisols

\section{Introduction}

Corn is a crop that plays an important role as the main food of Indonesian society after the rice. In addition to corn as food demand continues to increase along with the development of the livestock sector which uses corn as feed material [17]. Importance of corn plants to be developed extensively since corn is one commodity that has a strategic role in fulfilling the nutritional needs, improve food security as well as the needs of industrial raw materials [14]. One of the main obstacles encountered in efforts to increase the production of corn, especially in Southeast Sulawesi is a type of soil which was dominated by Ultisols. Ultisols is a land that has a fairly advanced level of development, characterized by the cross section of deep soil, clay fraction rise along with the depth of this soil has the potential to Al toxicity and poor organic matter content. It also poor soil nutrient content, especially $\mathrm{P}$ and exchangeable cations such as $\mathrm{Ca}, \mathrm{Mg}, \mathrm{Na}, \mathrm{K}, \mathrm{Al}$ content is high, low cation exchange capacity and vulnerable to erosion [25].

Ultisols have a fairly extensive distribution covering almost $29.7 \%$ of the total the mainland of Indonesia that makes the land has an important role in the development of dryland farming in Indonesia [24]. Texture Ultisols usually varies greatly depending on parent material of soil. Ultisols are derived from granite that is rich in mineral quartz 
generally has a rough texture like sandy clay [26]. Ultisols reaction generally sour to very sour ( $\mathrm{pH} 5$ to 3.10 ), except Ultisols of limestone that have a neutral to slightly acid reaction ( $\mathrm{pH} 6.80$ to 6.50). Cation exchange capacity in Ultisols of granite, sediments and tuffs are low respectively cmol ranged from 2.90 to $7.50 \mathrm{~kg}-1,6.11$ to $13.68 \mathrm{cmol} \mathrm{kg-1}$

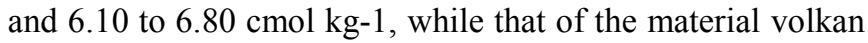
andesitic and limestone is high $(>17 \mathrm{cmol} \mathrm{kg}-1)$. The results of research [16], shows that some of the material volkan Ultisols, calcareous tuffs and limestone have a high cation exchange capacity. According to the results of research [8], that condition of Ultisols Abenggi villages are: $\mathrm{pH} 5.77, \mathrm{C}-$ Organic $1.92 \%, 0.17 \%$ Nitrogen, $12.75 \mathrm{ppm}$ Phosphorus and 0.22 me100g-1 Potassium. Such circumstances may result in less optimal crop production in general and in especially sweet corn. To cope with things like this, it is necessary to touch the utilization of biotechnology such as mycorrhiza fungi and liquid organic fertilizer.

Mycorrhiza fungi are fungi that are mutualistic symbiosis with plant roots [6]. While indigenous mycorrhiza fungi is a type of mycorrhiza are found in association with plant roots naturally without human intervention in the process of initial infection between mycorrhiza with host plants, for example the mycorrhiza fungi from grassland rhizosphere [10]. The results of research [9] showed that in the area of secondary forest plant root were found the kinds of mycorrhiza fungi such as Glomus sp, Gigaspora sp sp and Acalauspora sp with different number of spores. Similarly, the results of research [11], that there are 15 species of plants are found in association with mycorrhiza fungi with infection rates of between $60 \%$ - 90\%. According [22], that's infection of mycorrhiza fungi can enhance plant growth and the ability to utilize available nutrients in the soil. The colonization of mycorrhiza fungi on plant roots can expand the field of root uptake in the presence of external hyphae grow and develop through the roots [3]. The results of research [10], that the application of mycorrhiza fungi at a dose of 1 ton ha- 1 is able to increase the production of corn to 10 tonnes ha- 1 on Ultisols. Similarly, the results of research [8], application of mycorrhiza fungi can increase the production of corn ranged from 7.90 to 8.60 tonnes ha-1 compared to no provision of mycorrhiza fungi of 5.50 tonnes ha-1.

Organic fertilizer is the collective name for all kinds of organic materials of plant and animal origin that can be reformed into nutrients available to plants. The use of organic fertilizer could be a solution to reduce the excessive application of inorganic fertilizers due to the organic materials that can improve the physical, chemical and biological soil. Function organic fertilizer to the chemical properties of improving the cation exchange capacity, increase the availability of nutrients and increase the mineral weathering process. As to the biological properties that made the source of food for soil microorganisms such as fungi, bacteria and other microorganisms [7]. The liquid organic fertilizer containing potassium, which are crucial elements in any process plant metabolism, namely in synthesis and plays a role in maintaining good turgor pressure so as to allow the smooth metabolic processes and ensure the sustainability of cell elongation [18]. The advantages of liquid organic fertilizer is to quickly overcome nutrient deficiency, it does not matter in nutrient leaching and able to provide rapid nutrient [28].

\section{Methodology}

\subsection{Place and Time}

This research was conducted in the Abenggi of village, District of Landono, Regency of South Konawe, Province of Southeast Sulawesi and Laboratory of the Faculty of Forestry and Environmental Science Halu Oleo University Kendari, Indonesia took place from November, 2014 untill April, 2015.

\subsection{Materials and Tools}

The materials used in this study were raffia ropes, water, soil, mycorrhiza fungi, sweet corn seed, polybag (size $20 \mathrm{~cm}$ x $30 \mathrm{~cm}, 40 \mathrm{~cm} \mathrm{x} \mathrm{50cm)),} \mathrm{aquades,} 30 \%$ sucrose, Acero Formalin Alcohol (FAA), $10 \% \mathrm{KOH}$ solution, a solution of hydrogen $10 \%$ alkaline peroxide $\left(\mathrm{H}_{2} \mathrm{O}_{2}\right)$, a solution of $\mathrm{HCl}$ $1 \%$, dyes carbol fuchin $0.05 \%$, laktogliserol, filter paper and paper labels. The tools used were tillage tools, vernier caliper, machetes, meter, digital cameras, filter to see mycorrhizal spore size (mesh size of $5001 \mathrm{~m}, 2501 \mathrm{~m}, 901 \mathrm{~m}, 601 \mathrm{~m}$, and $50 \mathrm{~lm}$ ), analytical balance, autoclave, binocular microscope, glass measuring, petridish, pipettes, scissors, and stationery.

\subsection{Research Design}

This research is compiled using a randomized design block (RDB) with two factors. The first factor is doses of mycorrhiza fungi (M) with three levels: without mycorrhiza fungi for each planting hole $\left(\mathrm{M}_{0}\right), 20 \mathrm{~g}$ mycorrhiza fungi for each planting hole $\left(\mathrm{M}_{1}\right), 40 \mathrm{~g}$ mycorrhiza fungi for each planting hole $\left(\mathrm{M}_{2}\right)$ and the second factor is a liquid organic fertilizer (P) which comprises three levels of treatment: without liquid organic fertilizer $\left(\mathrm{P}_{0}\right), 250 \mathrm{ml}$ of liquid organic fertilizer for each plot $\left(50 \mathrm{ml} \mathrm{L}^{-1}\right.$ water $)\left(\mathrm{P}_{1}\right), 500 \mathrm{ml}$ of liquid organic fertilizer for each plot $\left(100 \mathrm{ml} \mathrm{L}^{-1}\right.$ water $)\left(\mathrm{P}_{2}\right)$. From these two factors obtained 9 combinations of each treatment was repeated 3 times in order to obtain the amount of 27 experimental units.

\subsection{Procedure}

Implementation procedures of the research are as follows:

(a) Preparation of land; land preparation includes cleaning, soil tillage, as well as the making of the plot.

(b) Application of mycorrhiza fungi; application of mycorrhiza fungi conducted simultaneously planting sweet corn plants given to each planting hole. The positions of mycorrhiza fungi are under seed of sweet corn [10]. Liquid organic fertilizer plant is given at the age of 7 days after planting. Sprinkled with the liquid organic fertilizer in the planting hole 
evenly on experimental plots.

(c) Planting; planting be done by drill, each planting holes gets 2 seed of sweet corn, with a spacing of 20 $\mathrm{cm} \times 75 \mathrm{~cm}$.

(d) Maintenance; plant maintenance includes weeding, watering and replanting. Weeding was done by removing or cleaning the grass or weed that grows on a plot, in order to avoid competition and nutrient uptake by weeds. Watering was done to maintain the condition of field capacity. Watering was done twice a day, morning and evening, if it does not rain. Watering is done starting from the beginning of planting until the plants germinate or grow normally. Stitching is done at the time the plant was 7 days after planting.

\subsection{Observation of Variables}

The variables were observed in this study include:

(a) The plant height; plant height is measured from the base of the stem to the tip of the highest leaf by using a meter at the age of 14,28 and 42 days after planting (DAP).

(b) The stem of diameter; stem diameter were measured using calipers at the age of 14, 28 and 42 DAP. The measurements were made approximately $15 \mathrm{~cm}$ from the ground.

(c) The weights of the cob with husk: weighed before corn cobs separated from its husk.

(d) The weights of the cob without husk; weighed after corn cobs separated from its husk.

(e) The length of the cob; measured from the base to the tip of a corn cob that contains the seeds.

(f) The diameter of the cob; measured by using a vernier caliper. The portions were measured, namely the base, middle and lower end portions cob containing seeds.

(g) The percentage of mycorrhiza fungi infection; preceded with staining roots. The steps in staining roots are as follows: (1) washing the roots with water (2) saving the FAA for fixation prior to painting, (3) soaking in $10 \% \mathrm{KOH}$ and heat with an autoclave for $15-20$ minutes at $121^{\circ} \mathrm{C}$, (4) washing with distilled water 3 times, (5) soaking in hydrogen peroxide outsmart $10 \%\left(\mathrm{H}_{2} \mathrm{O}_{2}\right)$, (6) washing with distilled water 3 times, (7) soaking with $\mathrm{HCl} 1 \%$, (8) wasting $\mathrm{HCl}$ without washed with distilled water, (9) soaking in carbon fuchin with concentration of $0.05 \% \mathrm{w} / \mathrm{v}$ in laktogliserol and heat at $900 \mathrm{C}$ for several hours or in an autoclave at $1210 \mathrm{C}$ for 15 minutes, (10) removing the paint and soak the roots in laktogliserol, and (11) observing the roots sample using a microscope (Brundrett, 2004) in [11]. The Observations were carried out using a dissecting microscope at a magnification of 40 times. Furthermore, mycorrhiza fungi infection was calculated by using the formula proposed by Brian and Schults (1980) in [10]: IP = $\frac{\mathrm{r} 1}{\mathrm{r} 1+\mathrm{r} 2} \times 100 \%$.

Note:
$\mathrm{IP}=$ the percentage of mycorrhiza fungi infection

$\mathrm{r} 1=$ the number of root infected examples

$\mathrm{r} 2=$ the number of root not infected examples

\subsection{Data Analysis}

Data of each variable were observed were analyzed by variance of analysis. If the F count is greater than the F table, then continued with Duncan Range Multiple Test (DRMT) at $95 \%$ confidence level.

\section{Result and Discussion}

\subsection{Plant Height and Stem of Diameter}

Application independently of mycorrhiza fungi significantly affect to the average height of sweet corn plants at 14 DAP and significantly affect to stem of diameter at 14 and 42 DAP (Table 1).

Table 1. Effect of application of mycorrhiza fungi to the average height of sweet corn plants (cm), stem of diameter $(\mathrm{cm})$ at the age of 14 and $42 \mathrm{DAP}$.

\begin{tabular}{|c|c|c|c|c|}
\hline \multirow{4}{*}{ Treatment } & \multicolumn{4}{|l|}{ Parameter } \\
\hline & \multirow{3}{*}{$\begin{array}{l}\begin{array}{l}\text { average height of } \\
\text { sweet corn plants }(\mathrm{cm})\end{array} \\
14 \text { DAP }\end{array}$} & \multicolumn{2}{|c|}{$\begin{array}{l}\text { stem of diameter } \\
\text { (cm) }\end{array}$} & \\
\hline & & 14 & & \\
\hline & & DAP & DAP & \\
\hline \multicolumn{5}{|l|}{ without } \\
\hline $\begin{array}{l}\text { mycorrhiza fungi } \\
\left(\mathrm{M}_{0}\right)\end{array}$ & $22.62 \mathrm{~b}$ & $0.23 \mathrm{~b}$ & $2.59 \mathrm{a}$ & \\
\hline $\begin{array}{l}20 \mathrm{~g} \text { mycorrhiza } \\
\text { fungi }\left(\mathrm{M}_{1}\right)\end{array}$ & $22.78 \mathrm{~b}$ & $0.24 \mathrm{~b}$ & $2.48 \mathrm{ab}$ & \\
\hline $\begin{array}{l}40 \mathrm{~g} \text { mycorrhiza } \\
\text { fungi }\left(\mathrm{M}_{2}\right)\end{array}$ & $27.23 \mathrm{a}$ & $0.27 \mathrm{a}$ & $2.30 \mathrm{~b}$ & \\
\hline \multicolumn{5}{|l|}{$\mathrm{UJBD}_{0,05}$} \\
\hline $2=$ & 2.330 & 0.021 & 0.222 & 0.033 \\
\hline $3=$ & 2.443 & 0.022 & 0.233 & 0.035 \\
\hline
\end{tabular}

Note: The numbers are followed by the same letters in the same column, no significant based DRMT 95\%

Table 1, the highest average of sweet corn height on 14 DAP obtained in the treatment of $\mathrm{M}_{2}$ as $27.23 \mathrm{~cm}$ were significantly different with treatment of $\mathrm{M}_{1}$ and $\mathrm{M}_{0}$, but $\mathrm{M}_{1}$ does not differ significantly with treatment of $\mathrm{M}_{0}$. The highest average of sweet corn stem diameter on 42 DAP obtained in the treatment $\mathrm{M}_{0}$ is $2.59 \mathrm{~cm}$ were significantly different with treatment of $\mathrm{M}_{2}$, but did not differ significantly with treatment of $\mathrm{M}_{1}$. [22], states that the granting of mycorrhiza fungi cause the growth of the plant stem is greater than the plants that are not infected by mycorrhiza fungi. The results of resesarch showed that mycorrhiza fungi and organic liquid fertilizer is very real effect on plant height and stem diameter of sweet corn plants at the age of 14 DAP and 42 DAP, while at the age of 28 DAP provides no real influence. It is thought to during the vegetative plant roots have not been infected by mycorrhiza fungi perfectly so that the role of mycorrhiza fungi helping the roots to expand nutrient absorption area has not gone well. According [27], mycorrhiza fungi develop in the cortex, where the infection is influenced by anatomical roots and the age of the plant. 
Although mycorrhiza fungi are given in plants but available nutrients phosphorus is still below the optimal requirements for the growth of corn plants, this is because the phosphorus content at a lower marginal land. On the other hand, needs a lot of plants to phosphorus relative to the process of photosynthesis, respiration and energy metabolism. [26], stating that the nutrient content in soil is generally low due to marginal alkaline leaching takes place intensively.

Application of liquid organic fertilizer independently significantly affect the average plant height at 14 DAP, whereas at 28 and 42 DAP did not affect significantly (Table 2).

Table 2. Effect of application of organic liquid fertilizer to the average height of corn plants (cm) at the age of 14 DAP.

\begin{tabular}{lll}
\hline Treatment & $\begin{array}{l}\text { average height of sweet corn } \\
\text { plants }(\mathbf{c m})\end{array}$ & DRMT 0.05 \\
\hline Without liquid organic & $22.68 \mathrm{~b}$ & $2=2.330$ \\
fertilizer ( $\left.\mathrm{P}_{0}\right)$ & $24.11 \mathrm{ab}$ & $3=2.443$ \\
$50 \mathrm{ml} \mathrm{L}^{-1}$ water $\left(\mathrm{P}_{1}\right)$ & $25.84 \mathrm{a}$ & \\
$100 \mathrm{ml} \mathrm{L}^{-1}$ water $\left(\mathrm{P}_{2}\right)$ & \\
\hline
\end{tabular}

Note: The numbers are followed by the same letters in the same column, no significant based DRMT 95\%

Table 2 shows that the highest average of sweet corn height obtained at the treatment of $\mathrm{P}_{2}$ is $25.84 \mathrm{~cm}$ were different unreal with treatment of $\mathrm{P}_{1}$, but significantly different with treatment of $\mathrm{P}_{0}$. The treatment of $\mathrm{P}_{1}$ did not differ significantly with treatment of $\mathrm{P}_{0}$ and $\mathrm{P}_{2}$. The treatment of $\mathrm{P}_{1}$ had no significant to treatment of $\mathrm{P}_{0}$, but significantly different from treatment of $\mathrm{P}_{2}$. The results of research showed that the application of liquid organic fertilizer significantly affected to stem diameter, corncob with husk, cob length, cob diameter and the number of seed rows $\mathrm{cob}^{-1}$. [19] declare that the liquid organic fertilizer containing elements of potassium which play an important role in every metabolic process plants, namely in synthesis and plays a role in maintaining good turgor pressure so as to allow the smooth metabolic processes and ensure the sustainability of cell elongation. In the vegetative phase liquid organic fertilizer only to give effect to the corn plant height age of 14 DAP. It is suspected liquid organic fertilizer dose given is still very low, so it has not significantly affected the growth of sweet corn plants.

Table 3. Effect of applications of mycorrhiza fungi and liquid organic fertilizer to the average height of corn plants $(\mathrm{cm})$ at the age of 42 DAP.

\begin{tabular}{|c|c|c|c|c|}
\hline \multirow{3}{*}{ mycorrhiza fungi } & \multicolumn{3}{|c|}{ Liquid organic fertilizer } & \multirow{3}{*}{ DRMT $_{0.05}$} \\
\hline & $\begin{array}{l}\text { Without } \\
\text { liquid organic } \\
\text { fertilizer }\end{array}$ & $50 \mathrm{ml} \mathrm{L}^{-1}$ & $100 \mathrm{ml} \mathrm{L}^{-1}$ & \\
\hline & $\left(\mathbf{P}_{0}\right)$ & $\left(\mathbf{P}_{1}\right)$ & $\left(\mathbf{P}_{2}\right)$ & \\
\hline Without mycorrhiza & $202.13 \mathrm{a}$ & $192.97 \mathrm{~b}$ & $193.07 \mathrm{~b}$ & $2=12.747$ \\
\hline fungi $\left(\mathrm{M}_{0}\right)$ & $\mathrm{p}$ & $\mathrm{p}$ & $\mathrm{p}$ & $3=13.368$ \\
\hline 20 g mycorrhiza & $193.07 \mathrm{a}$ & $212.57 \mathrm{a}$ & $198.43 \mathrm{ab}$ & \\
\hline fungi $\left(\mathrm{M}_{1}\right)$ & $q$ & $\mathrm{p}$ & $q$ & \\
\hline $40 \mathrm{~g}$ mycorrhiza & $202.80 \mathrm{a}$ & $212.57 \mathrm{a}$ & $208.73 \mathrm{a}$ & \\
\hline fungi $\left(\mathrm{M}_{2}\right)$ & $\mathrm{p}$ & $\mathrm{P}$ & $\mathrm{p}$ & \\
\hline
\end{tabular}

Note: The numbers are followed by letters are not the same in the column $(a b)$ and rows (p-q) the same significantly different based DRMT 95\%
Application of mycorrhiza fungi and liquid organic fertilizer significantly affect the average plant height at 42 DAP, while at the age of 14 and 28 DAP does not affect significantly (Table 3).

Table 3 shows that the average height of the highest plant found in the combination treatment of the mycorrhiza fungi as $20 \mathrm{~g}$ planting hole $\mathrm{e}^{-1}$ and liquid organic fertilizer as $50 \mathrm{ml}$ $\mathrm{L}^{-1}$ and $40 \mathrm{~g}$ planting hole $\mathrm{e}^{-1}$ respectively as $212.57 \mathrm{~cm}$. At the level of interaction without liquid organic fertilizer and without mycorrhiza fungi on plant height and stem diameter at the age of 42 DAP provides no real influence. It is presumably related to the conditions of weather especially rainfall is quite high at the study site. This is supported by results of research [1], that information on climate characteristics was an important factor for determination of areas for maize cultivation.

\subsection{The Weight of Cob Without Husk}

Application of mycorrhiza fungi and liquid organic fertilizer significantly affect to weight of cob without husk (Table 4).

Table 4. Effect of application of mycorrhiza fungi and liquid organic fertilizer to the average weight of cob without husk ( $\mathrm{kg})$.

\begin{tabular}{|c|c|c|c|c|}
\hline \multirow{3}{*}{$\begin{array}{l}\text { mycorrhiza } \\
\text { fungi }\end{array}$} & \multicolumn{3}{|c|}{ Liquid organic fertilizer } & \multirow{3}{*}{ DRMT $_{0.05}$} \\
\hline & $\begin{array}{l}\text { Without liquid } \\
\text { organic fertilizer }\end{array}$ & $50 \mathrm{ml} \mathrm{L}^{-1}$ & $100 \mathrm{ml} \mathrm{L}^{-1}$ & \\
\hline & $\left(\mathbf{P}_{0}\right)$ & $\left(\mathbf{P}_{1}\right)$ & $\left(\mathbf{P}_{2}\right)$ & \\
\hline \multirow{6}{*}{$\begin{array}{l}\text { Without } \\
\text { mycorrhiza } \\
\text { fungi }\left(\mathrm{M}_{0}\right) \\
20 \mathrm{~g} \text { mycorrhiza } \\
\text { fungi }\left(\mathrm{M}_{1}\right) \\
40 \mathrm{~g} \text { mycorrhiza } \\
\text { fungi }\left(\mathrm{M}_{2}\right)\end{array}$} & $0.20 \mathrm{~b}$ & $0.20 \mathrm{c}$ & $0.23 \mathrm{~b}$ & $2=0.036$ \\
\hline & $\mathrm{p}$ & $\mathrm{P}$ & $\mathrm{p}$ & $3=0.037$ \\
\hline & $0.28 \mathrm{a}$ & $0.28 \mathrm{~b}$ & $0.28 \mathrm{a}$ & \\
\hline & $\mathrm{p}$ & $\mathrm{P}$ & $\mathrm{p}$ & \\
\hline & $0.25 \mathrm{a}$ & $0.32 \mathrm{a}$ & $0.32 \mathrm{a}$ & \\
\hline & $q$ & $\mathrm{P}$ & $\mathrm{p}$ & \\
\hline
\end{tabular}

Note: The numbers are followed by letters are not the same in the column (ab) and rows (pq) the same significantly different based DRMT 95\%

Table 4 shows that the average weight of cob without husk is highest in the combined treatment of $40 \mathrm{~g}$ mycorrhiza fungi planting hole ${ }^{-1}$ and liquid fertilizer $50 \mathrm{ml} \mathrm{L}^{-1}$ and $40 \mathrm{~g}$ mycorrhiza fungi planting hole ${ }^{-1}$ each $0.32 \mathrm{~kg}$. Independent influence of mycorrhiza on the cob with husk weight, the weight of cob without husk, cob length, cob diameter and number of lines of seeds $\mathrm{cob}^{-1}$ gives a significant influence. This shows that when the corn crop enters the generative phase, the number of mycorrhiza hyphae formed more so that the effectiveness of the absorption of nutrients to support plant growth becomes better. The treatment of mycorrhiza fungi as $40 \mathrm{~g}$ planting hole ${ }^{-1}$ gives a better effect on the growth and yield of sweet corn. This is because the mycorrhiza fungi infection on the roots of sweet corn more numerous so that the effectiveness of the absorption of nutrients to support the growth and yield of sweet corn to be better.

Application of mycorrhiza fungi and liquid organic fertilizer significantly affected the plant height at 42 DAP and weight cob without husk. It is thought to increase 
mycorrhiza fungi and liquid organic fertilizer can be complementary in supporting the growth and crop yield. Mycorrhiza fungi play a role in improving the tolerance of crops to the conditions of degraded land, helps the roots to increase the absorption of water and nutrients in the soil. While liquid organic fertilizer containing potassium, which are crucial elements in any process plant metabolism, namely in synthesis and plays a role in maintaining good turgor pressure so as to allow the smooth metabolic processes and ensure the sustainability of cell elongation [18].

\subsection{Cob Length (cm), Cob Diameter (cm) and the Number of Seed Rows Cob $^{-1}$}

Application of mycorrhiza fungi significantly affect to cob length, cob diameter and number of seeds $\operatorname{cob}^{-1}$ (Table 5). While the combination of application of mycorrhiza fungi and organic fertilizer no real effect.

Table 5. Effect of the application of mycorrhiza fungi on the average length of cob (cm), cob diameter (cm) and the number of seed rows $\mathrm{cob}^{-1}$.

\begin{tabular}{llll}
\hline Treatment & variable & & \\
\cline { 2 - 4 } & $\begin{array}{l}\text { length of cob } \\
(\mathbf{c m})\end{array}$ & $\begin{array}{l}\text { cob diameter } \\
(\mathbf{c m})\end{array}$ & $\begin{array}{l}\text { number of } \\
\text { seed rows } \text { cob }^{-1}\end{array}$ \\
\hline $\begin{array}{l}\text { Without mycorrhiza } \\
\text { fungi }\left(\mathrm{M}_{0}\right)\end{array}$ & $18.89 \mathrm{~b}$ & $3.73 \mathrm{~b}$ & $14.44 \mathrm{~b}$ \\
$\begin{array}{l}20 \mathrm{~g} \text { mycorrhiza fungi } \\
\left(\mathrm{M}_{1}\right)\end{array}$ & $20.89 \mathrm{a}$ & $3.96 \mathrm{a}$ & $16.00 \mathrm{a}$ \\
$40 \mathrm{~g}$ mycorrhiza fungi & $21.46 \mathrm{a}$ & $4.04 \mathrm{a}$ & $16.67 \mathrm{a}$ \\
$\left(\mathrm{M}_{2}\right)$ & & & \\
$\mathrm{DRMT}_{0,05}$ & 1.197 & 0.117 & 1.267 \\
$2=$ & 1.155 & 0.123 & 1.328 \\
\hline $3=$
\end{tabular}

Note: The numbers are followed by the same letters in the same column, no significant based DRMT 95\%

Table 5 shows that the average length of the highest cob sweet corn was obtained in treatment of $\mathrm{M}_{2}$ as $21.46 \mathrm{~cm}$ different unreal with treatments of $\mathrm{M}_{1}$, but significantly different with treatment of $\mathrm{M}_{0}$. The cob diameter of sweet corn highest was obtained in treatment of $\mathrm{M}_{2}$ as $4.04 \mathrm{~cm}$ were no significant with treatment of $\mathrm{M}_{1}$ but significantly different with treatment of $\mathrm{M}_{0}$. The number of seed row cobs ${ }^{1}$ highest obtained at treatment of $\mathrm{M}_{2}$ as $16.67 \mathrm{~cm}$ different unreal with treatment of $\mathrm{M}_{1}$, but significantly different with treatment of $\mathrm{M}_{0}$. The size and number of seeds related to the uptake of nutrients accumulated in the form of sink as a result of mycorrhiza fungi infection on the roots of plants. Mycorrhiza fungi infection is related to metabolic processes such as photosynthesis that plants run optimally to ensure continuity of symbiosis between the plants with mycorrhiza fungi [5]. [2], suggests that the increase in Phosphorus uptake by plants due to volume expansion of the plant's roots and the acceleration of the movement of Phosphorus into hyphae of mycorrhiza fungi. Furthermore, Phosphorus is taken by the external hyphae transferred to arbuscular through internal hyphae that can increase crop Phosphorus uptake [23]. The effectiveness of mycorrhiza fungi thought to as a result of differences in the adaptation of species and nature of each mycorrhiza fungi [10]. [4] report that Gigaspora sp has a high tolerance to changes in soil chemistry compared to Acaulospora sp and Glomus sp. The different types of mycorrhiza fungi are contributing to the abundance populations of mycorrhiza fungi, further affect the ability to compete among types of mycorrhiza fungi in occupying space and obtain nutrients from the host plant root exudates as a source of energy [12:15].

\subsection{Percentage of Mycorrhiza Infection on the Roots of Sweet Corn Plant}

The average percentage of mycorrhizal infection on the roots of corn plants are listed in Table 6 .

Table 6. Average percentage of mycorrhiza infection (\%) on the roots of corn plants.

\begin{tabular}{lll}
\hline Treatment & $\begin{array}{l}\text { Average percentage of } \\
\text { mycorrhiza infection }(\%)\end{array}$ & DRMT $_{\mathbf{0}, 05}$ \\
\hline Without mycorrhiza fungi $\left(\mathrm{M}_{0}\right)$ & $0.00 \mathrm{c}$ & $2=4.662$ \\
20 g mycorrhiza fungi $\left(\mathrm{M}_{1}\right)$ & $20.00 \mathrm{~b}$ & $3=4.889$ \\
40 g mycorrhiza fungi $\left(\mathrm{M}_{2}\right)$ & $27.78 \mathrm{a}$ & \\
\hline
\end{tabular}

Note: The numbers are followed by the same letters in the same column, no significant based DRMT 95\%

Table 6 shows that the average of percentage of mycorrhiza fungi infection on the roots of sweet corn plants is highest in the treatment of $\mathrm{M}_{2}$ as $27.78 \%$ which is significantly different from the treatment of $\mathrm{M}_{1}$ and $\mathrm{M}_{0}$. The roots of sweet corn were infected by mycorrhiza fungi characterized by vesicles, internal and external hyphae. The vesicles was thick-walled structure and serves as a repository and exchange of food reserves. characterized external hyphae are outside the root cell growth, is an important structure as it continues to expand its distribution which aims to search for sources of food and organic and inorganic nutrients in the soil needed by the plant, so that the hyphae is better known as a helper, and the internal hyphae hyphae which serves as a liaison between vesicles vesicles with the other one. [20] report that an increase in uptake of $\mathrm{N}, \mathrm{P}, \mathrm{K}, \mathrm{Ca}$ and $\mathrm{Mg}$ by plants when given the addition of mycorrhiza fungi.

Sweet corn plant roots more quickly associated with mycorrhiza fungi, converselly the mycorrhiza fungi otherwise would acquire the nutrient phosphorus from root exudates of plants that have been infected as a source of energy [13]. The result of this research shows that the higher dose given mycorrhiza fungi on sweet corn higher the infection on sweet corn roots. These results are in accordance with the statement of [3] that the surface area of the infected root mycorrhiza fungi 10 times greater than in uninfected mycorrhizae. The roots of which has an area greater absorption will have a chance to absorb nutrients larger, therefore the plant in association with mycorrhiza fungi will be able to improve its capacity to absorb nutrients and water. In additon, the roots of the plants have a metabolic rate 2-4 times higher when compared the root crops was not infected by mycorrhiza [21]. 


\section{Conclusions}

From the results of this reserach, the following conclusions can be drawn:

(a) The interaction between mycorrhiza fungi and liquid organic fertilizer has a significant effect on the plant height age 42 days after planting and cob weight without husk with the best results obtained in the treatment of mycorrhiza fungi as $40 \mathrm{~g} \mathrm{hole}^{-1}$ with liquid organic fertilizer as $50 \mathrm{ml} \mathrm{L}^{-1}$ water.

(b) Application the mycorrhiza fungi as $40 \mathrm{~g} \mathrm{hole}^{-1}$ gives the best results on the growth and yield of sweet corn.

\section{Acknowledgements}

The author would like to thank to the Ministry of Research, Technology and Higher Education of the Republic of Indonesia for the financial assistance through the scheme of National Priorities Research Grant Master Plan for the Acceleration and Expansion of Indonesian Economic Development 2011-2025 in 2014, 2015. The author also thank to the Rector of Halu Oleo University and the Chairman of the Research Institute of Halu Oleo University for the administrative of services.

\section{References}

[1] Aminuddin Mane Kandari, Sumbangan Baja, Ambo Ala, Kaimuddin, 2013. Agroecological zoning and land suitability assessment for maize (Zea mays L.) development in Buton regency Indonesia. J. International of Agriculture, Forestry and Fisheries. Vol.2. No. 6:202-211.

[2] Bolan. N. S., 1991. A Critical Review of the Role Mycorrhizal Fungi in the uptake of Phosphorus by Plants. J.of Plant and Soil. Vol.132. No.2:189-207.

[3] Brady, N.C., 2002. The Nature and Properties of Soils, Prentice Hall of India, New Delhi.

[4] Clark. R. B., 1997. Arbuscular Mycorrhizal Adaption, Spore Germination, Root Colonization and Host Plant Growth and Mineral Acquisition at Low pH. J.of Plant and Soil. Vol.192:15-22.

[5] Delvian, 2007. Penggunaan Asam Humik dalam Kultur Trapping Cendawan Mikoriza Arbuskula dari Ekosistem dengan Salinitas Tinggi. Jurnal Ilmu-Ilmu Pertanian Indonesia. Vol. 9. No. 2:124-129.

[6] Gonzalo.B.E. and A.Miguel, 2006. Mycorrhiza. An Ecological Alternative for Sustainable Agriculture. Melalui $<$ http://www.micorrhizas.htm>.

[7] Hadisuwito, S., 2008. Membuat Pupuk Kompos Cair. PT Agromedia Pustaka. Jakarta.

[8] Halim dan F.S. Rembon, 2013. Peningkatan produksi tanaman jagung berbasis bioteknologi Mikoriza Indigenous Gulma. Laporan hasil penelitian MP3EI Dikti. Lembaga Penelitian Universitas Halu Oleo Kendari.

[9] Halim, 2012. Peran Mikoriza Indigen Terhadap Indeks Kompetisi antara Tanaman Jagung (Zea mays L.) dengan
Gulma Ageratum conyzoides. Berkala Penelitian Agronomi. Vol.1.No. 1: 86-92.

[10] Halim, 2009. Peran Mikoriza Indigenous Gulma Imperata cylindrica (L.) Beauv dan Eupatorium odorata (L.) terhadap Kompetisi Gulma dan Tanaman Jagung. Disertasi Program Doktor Universitas Padjadjaran Bandung.

[11] Halim, Fransiscus S Rembon, Aminuddin Mane Kandari, Resman, Asrul Sani, 2014. Characteristics of indigenous mycorrhiza of weeds on marginal dry land in South Konawe, Indonesia J. International of Agriculture, Forestry and Fisheries. Vol.3. No.6:459-463.

[12] Janos. D. P., 1992. Heterogenity and Scale in Tropical Vesicular Arbuscular Mycorrhiza Formation. CAB International. Wallingford.UK.

[13] Juge. C., J.Samson, C.Bestien, H.Vierheilig, A.Coughlan and Y.Pieche, 2002. Breaking Dormancy in Spores of the Arbuscular Mycorrhizal Fungus Glomus intraradies. A Critical Cold Storage Period. J. of Mycorrhiza. 12:37-42.

[14] Mazi. A., 2004. Kebijakan Strategi Pengembangan Sistem Produksi Jagung di Provinsi Sulawesi Tenggara dalam Kerangka Program Celebes Corn Belt (CCB). Prosiding Seminar IX Budidaya Pertanian Olah Tanah Konservasi Kerjasama dengan Himpunan Ilmu Gulma Indonesia, Universitas Gorontalo dan Pemerintah Daerah Provisnsi Gorontalo. Gorontalo.

[15] Moutoglis.P and P.Widden, 1996. Vesicular Arbuscular Mycorrhizal Spore Population in Sugar Maple (Acer saccharum marsh L.) Forest. J. of Mycorrhiza. Vol.6:91-97.

[16] Prasetyo B.H. dan D.A. Suriadikarta, 2006. Karakteristik, potensi, dan teknologi Pengelolaan tanah ultisol untuk Pengembangan pertanian lahan Kering di indonesia. Balai Besar Penelitian dan Pengembangan Sumberdaya Lahan Pertanian. Bogor.

[17] Purwono dan R.Hartono, 2011. Bertanam Jagung Unggul. PT. Penebar Swadaya. Jakarta.

[18] Purwowidodo, 2007. Telaah Kesuburan Tanah. Penerbit Angkasa. Bandung.

[19] Rao S., 1994. Mikroorganisme dan Pertumbuhan Tanaman. Penerbit Universitas Indonesia. Jakarta.

[20] Sadaghiani, M.R, Hassana, A, Barin, M., Danesh, Y.R., \& Sefidkon, F., 2010. Effects of arbuscular mycorrhizal (AM) fungi on growth, essential oil production and nutriends uptake in basil, Journal of Medicinal Plant Research. Vol.4.No.21: 2222-2228.

[21] Sieverding, E., 1991, Vesicular-Arbuscular Mychoryza Management in Tropical Agrosystems, Deutshe Gesellicaft Fur Tehnische, Germany.

[22] Sinwin, R.M., Mulyati dan Lolita, E.S., 2007. Peranan Kascing dan Inokulasi Jamur Mikoriza terhadap Serapan Hara Tanaman Jagung. Jurnal Ilmu Tanah. Faperta. Universitas Lampung.

[23] Smith. S. E., E.S.Dickon, F.A.Smith and V.P.Gianiazzi, 1993. Nutrient Transport between Fungus and Plant in Vesicular Arbuscular Mycorrhizal. Proceeding of Second Asian Conference on Mycorrhiza. Chiang Mai. Thailand. Biotrop Special Publication No.42 Seameo Biotrop. Bogor. 
[24] Subagyo, 2000. Kriteria Kesesuaian Lahan untuk Komoditas Pertanian. Badan Penelitian dan Pengembangan Penelitian. Pusat Penelitian Tanah. Indonesia.

[25] Subowo dan Prihatin, T.A, Kentjanasari, 1996. Pemanfaatan Biofertilizer untuk Meningkatkan Produktivitas Lahan Pertanian. Jurnal Litbang Pertanian 15 (1), Medan.

[26] Suharta, N. dan B.H. Prasetyo, 1986. Karakteristik TanahTanah Berkembang dari Batuan Granit di Kalimantan Barat. Pemberitaan Penelitian Tanah dan Pupuk 6:51-60.
[27] Talanca, H. A. dan Adnan. M., 2005. Mikoriza dan Manfaatnya Pada Tanaman. Balai Penelitian Tanaman Serealia. Prosiding Seminar Ilmiah dan Penemuan Tahunan PEI dan FKI xvi Komda. Sulawesi Selatan. ISBN: 979-9525-6-7.

[28] Waryanti, Sudarno, Sutrisno E., 2013. Studi Pengaruh Penambahan Sabut Kelapa pada Pembuatan Pupuk Cair dari Limbah Air Cucian Ikan Terhadap Kualitas Unsur Hara Makro (CNPK). FT UNDIP. Semarang. 